\title{
Not Known if Additional Molecular Studies Were Performed
}

National Cancer Institute

\section{Source}

National Cancer Institute. Not Known if Additional Molecular Studies Were Performed. NCl Thesaurus. Code C160386.

An indication that it is not known whether additional molecular analysis was performed during the study. 